\title{
Photochemical efficiency in bean plants (Phaseolus vulgaris L. and Vigna unguiculata L. Walp) during recovery from high temperature stress
}

\author{
Ernany Santos Costa1, Ricardo Bressan-Smith1 ${ }^{*}$, Jurandi Gonçalves de Oliveira1, Eliemar Campostrini'1 \\ and Carlos Pimentel2
}

\begin{abstract}
1 Setor de Fisiologia Vegetal, Universidade Estadual do Norte Fluminense, Av. Alberto Lamego, 2000, CEP 28015-620, Campos dos Goytacazes, RJ, Brasil; 2 Departamento de Fitotecnia, Universidade Federal Rural do Rio de Janeiro, CEP 23851-970, Seropédica, RJ,Brasil; *Corresponding author: brsmith@uenf.br

Received: 05/03/2002, Accepted: 18/07/2002
\end{abstract}

Bean (Phaseolus vulgaris L., cv. Carioca and cv. Negro Huasteco) and cowpea plants (Vigna unguiculata L. Walp cv. Epace 10) were grown in a growth chamber with PPF at leaf level of $200 \mu \mathrm{mol} \cdot \mathrm{m}^{-2} \cdot \mathrm{s}^{-1}$ and air temperature $25 \pm 1{ }^{\circ} \mathrm{C}$. The first fully expanded pair of leaves of 12-day-old plants was submitted to high temperature stress $(25,30,35,40,45$ and $48{ }^{\circ} \mathrm{C}$ ) for $1.5 \mathrm{~h}$. The photochemical efficiency of PSII during recovery was monitored by means of chlorophyll $a$ fluorescence at six different times $(0.5,1,2,4,24$, and $48 \mathrm{~h})$ after stress, at $25{ }^{\circ} \mathrm{C}$, using a modulated fluorimeter. Increasing temperature promoted an increase in $\mathrm{F}_{\phi}$ at $45{ }^{\circ} \mathrm{C}$, possibly associated with dissociation of the light harvesting complex from the reaction centre of PSII, but a decrease was observed at $48{ }^{\circ} \mathrm{C}$ in all cultivars. $F_{\max }$ decreased at $48{ }^{\circ} \mathrm{C}$ in Carioca and Negro Huasteco, but not in Epace 10, showing a possible correlation between heat tolerance and $F_{\max }$ for this cultivar. The low values of $F_{\max }$ in Carioca and Negro Huasteco indicated a loss of PSII activity followed by death of these plants. $F_{v} / F_{\max }$ did not vary in Epace 10 but varied in Carioca and Negro Huasteco with increasing temperatures.

Key words: Chlorophyll $a$ fluorescence, heat stress, photosynthesis.

Eficiência fotoquímica em plantas de feijão (Phaseolus vulgaris L. e Vigna unguiculata L. Walp) durante a recuperação do estresse por alta temperatura: Utilizaram-se plantas de feijão (Phaseolus vulgaris L. cv Carioca e Negro Huasteco) e caupi (Vigna unguiculata L. Walp, cv Epace 10) crescidas em câmara controlada com FFF de 200 $\mu \mathrm{mol} . \mathrm{m}^{-2} . \mathrm{s}^{-1}$ e temperatura média do ar $25 \pm 1{ }^{\circ} \mathrm{C}$. Aos 12 ou 13 dias, as plantas foram submetidas aos tratamentos de temperatura $\left(25,30,35,40,45\right.$ e $\left.48{ }^{\circ} \mathrm{C}\right)$ por $1,5 \mathrm{~h}$. A eficiência fotoquímica do PSII foi monitorada, durante a recuperação das plantas, por meio da fluorescência da clorofila $a$, em seis períodos $(0,5 ; 1,2,4,24$, e $48 \mathrm{~h})$ após a indução do estresse. As variáveis da fluorescência da clorofila a foram obtidas com um fluorímetro de luz modulada a $25^{\circ} \mathrm{C}$. A temperatura de $45{ }^{\circ} \mathrm{C}$ provocou um aumento $\mathrm{em} \mathrm{F}_{\phi}$, com um decréscimo a $48{ }^{\circ} \mathrm{C}$ para todas as cultivares. Houve uma queda no valor da $F_{\max }$ a $48{ }^{\circ} \mathrm{C}$ para Carioca e Negro Huasteco, mas não para Epace 10, mostrando uma possível correlação entre queda na $F_{\max }$ e suscetibilidade dessas cultivares à alta temperatura. Os baixos valores de $F_{\max }$ ocorridos a $48{ }^{\circ} \mathrm{C}$, indicam perda da atividade do PSII e foi precedido pela morte das plantas. Com o aumento da temperatura não houve alterações na razão $F_{v} / F_{\max }$ para Epace 10 ao passo que Carioca e Negro Huasteco atingiram valores nulos a $48{ }^{\circ} \mathrm{C}$, mostrando a discrepância das cultivares em relação a alta temperatura.

Palavras-chave: fluorescência da clorofila $a$, temperatura supra-ótima, fotossíntese.

Abbreviations - LHCII, light harvesting complex; P680, PSII reaction centre; Rubisco, Ribulose-1,5-bisphosphate carboxylase/oxygenase; ATP, adenosine triphosphate; NADPH, nicotinamide adenine dinucleotide phosphate - reduced form; PPF, photosynthetic photon flux; PSI, photosystem I; PSII, photosystem II; $\mathrm{F}_{\phi}$, initial fluorescence; $\mathrm{F}_{\max }$, maximum fluorescence; $F_{v} / \mathrm{F}_{\max }$, PSII photochemical efficiency. 


\section{INTRODUCTION}

Crops are exposed to periods of heat stress during life their cycle. The optimum temperature for the most species ranges from 25 to $35{ }^{\circ} \mathrm{C}$. Above this value, a decline in the photosynthetic rate is observed (Berry and Björkman, 1980; Pimentel 1998). Under natural conditions, a momentary water deficit at the daily warm hours is observed and this can promote stomata closure. Consequently, the temperature of the leaves exposed directly to the sun can be equal or higher than the air temperature. This elevation of leaf temperature can result in biochemical and biophysical disturbance in the mesophyll, which can be reversible or not (Berry and Björkman, 1980).

In bean plants, photosynthesis shows a negative response to rising temperatures (Masaya and White, 1991). According to Jones (1971), the optimum temperature for photosynthesis in bean leaves is $25^{\circ} \mathrm{C}$, showing decay with its continuous increase. This is particularly interesting because studies have shown that optimum temperatures for bean plants above $25^{\circ} \mathrm{C}$ may be due to genetic breeding. A study presented by Pastenes and Horton (1996b) showed the potential photosynthetic rate of the Barbucho recombinant inbred line reaching maximum values at $35{ }^{\circ} \mathrm{C}$.

The main effects of high temperature on photosynthesis result from alterations in thylacoid physical-chemical properties (Gilmore and Govindjee, 1999). Besides inducing an increase in the lipid matrix fluidity (Raison et al., 1982) with consequent formation of unilayer structure, high temperature provokes disturbances in the photosynthetic apparatus organization, as follows: (a) destruction of the oxygen evolution complex; (b) dissociation of the light harvesting complex of PSII accompanied by variations in energy distribution between PSII and PSI and (c) inactivation of the PSII reaction centre (P680), that disturbs the grana stacking (Gounaris et al., 1983; Enami et al., 1994; Yamane et al., 1998). All these events result in photochemical and carboxylative efficiency losses, and serious metabolic restrictions in the Calvin cycle, such as inactivation of Ribulose-1,5-bisphosphate carboxylase/oxygenase (Rubisco) and variations in the metabolic pool, especially ATP and NADPH availability (Pastenes and Horton, 1996b).

In relation to photochemical efficiency, an increase in initial fluorescence $\left(\mathrm{F}_{\phi}\right)$ has been observed with rising temperatures. In some situations, $\mathrm{F}_{\phi}$ can be used as an indicator for irreversible damage in PSII (Pastenes and Horton, 1996a), associated to LHCII dissociation II (Briantais et al., 1996; Yamane et al., 1998) and blocking the electron transference in the reductant side of PSII.

In wheat and barley plants, identification of high temperature tolerance can be positively correlated with maximum $F_{\phi}$ (Havaux et al., 1988). However, Yamane et al. (1997) suggested that the inactivation of the PSII reaction centre, caused by denaturation of chlorophyllprotein complexes in response to high temperature, correlates with decay in $F_{\max }$ values. Changes in these fluorescence variables cause alterations in the $F_{v} / F_{\max }$ ratio, indicating a disturbance in photochemical activity of photosynthesis. The $F_{v} / F_{\max }$ ratio has been inferred as an indicator of environmental stresses, such as high temperature, water insufficiency, light excess and others, because it is easy and fast to measure (Maxwell and Johnson, 2000).

The present study analysed the temperature response of chlorophyll fluorescence $\left(F_{\phi}, F_{\max }\right.$ e $\left.F_{v} / F_{\max }\right)$ in bean (Phaseolus vulgaris L.) and cowpea plants [Vigna unguiculata (L.) Walp] submitted to optimal and supraoptimal temperatures. In addition, the response of the photosynthetic apparatus to high temperature was evaluated during the recovery period.

\section{MATERIAL AND METHODS}

Plant material and growth conditions: Photochemical measurements were performed in two bean species, the common bean (Phaseolus vulgaris L., cvs. Carioca and Negro Huasteco) and cowpea (Vigna unguiculata L., cv. Epace 10). Initially, the seeds were sown on wet towel paper in a germinator equiped with a temperature sensor. The temperature $\left(30^{\circ} \mathrm{C}\right.$ day and $20{ }^{\circ} \mathrm{C}$ night $)$ and photoperiod ( $8 \mathrm{~h}$ light and $16 \mathrm{~h}$ dark) used according to the recommendations of Regra para Análise de Sementes, (SNDA, 1992).

After three days, the plants were thinned and transferred to $0.3 \mathrm{~L}$ plastic pots containing organic substrate. The plants were grown in a Biotronette IV (LabLine Instruments Inc., USA) environmental chamber or 10 or $11 \mathrm{~d}$, sufficient time for the primary leaves to reach maximum size. The chamber consisted of eight fluorescent lamps allowing a photosynthetic photon flux 
(PPF) of $200 \mu \mathrm{mol} . \mathrm{m}^{-2} . \mathrm{s}^{-1}$ with $12 \mathrm{~h}$ photoperiod. The temperature and relative air humidity $(\mathrm{RH})$ were registered every hour by means of automatic sensors (Model 250, Spectrum Technologies, USA) coupled to a data logger (WatchDog Data Logger, Spectrum Technologies, USA), providing $25^{\circ} \mathrm{C}$ and $22^{\circ} \mathrm{C}$ thermal regimen and $48 \%$ and $72.5 \% \mathrm{RH}$ day and night, respectively.

High temperature treatment: The plants were closed in a temperature-controlled chamber JP-100 (J-Prolab, Brazil) and the temperature was monitored constantly by a digital thermometer thermopar type (Digi-Thermo, China) at the leaf surface level, providing a mean variation of $\pm 0.5^{\circ} \mathrm{C}$ in relation to the desired temperature. A light panel (with incandescent lamps) was installed inside the chamber during the stress submission permitting a PPF of 80 $\mu \mathrm{mol} . \mathrm{m}^{-2} \cdot \mathrm{s}^{-1}$.

The plants were previously standardized on a photochemical efficiency ratio $\left(F_{v} / F_{\max }\right)$ basis, and those with values inferior to 0.800 were disregarded (see fluorescence measurement). A set of five plants was incubated separately at $25,30,35,40,45$ and $48{ }^{\circ} \mathrm{C}$ for $1.5 \mathrm{~h}$. After stress treatment, the plants were taken to the bench lab where fluorescence measurements were taken during recovery at the following times: $0.5,1,2,4,24$ and $48 \mathrm{~h}$. All the measurements were taken at $25^{\circ} \mathrm{C}$.

The experiments followed a factorial arrangement in randomised blocks, each one with five replications. All data were subjected to means and standard deviation calculation.

Chlorophyll fluorescence: Modulated chlorophyll a fluorescence was measured by means of a MINI-PAM fluorimeter (Walz, Germany). After heat treatment, the leaves were dark-adapted for $30 \mathrm{~min}$ at $\sim 25^{\circ} \mathrm{C}$ using appropriate leaf clips (DLC-8). After this period some recovery probably occurred but this was ignored. Initial fluorescence $\left(\mathrm{F}_{\phi}\right)$ was obtained with low intensity modulated light $\left(<0.1 \mu \mathrm{mol} \cdot \mathrm{m}^{-2} \cdot \mathrm{s}^{-1}\right)$ used for limiting its effect in variable fluorescence. Maximum fluorescence was determined with a light saturation pulse of $0.3 \mathrm{~s}$, promoting the closure of reaction centres of PSII. The emitted diode light lasted $0.3 \mathrm{~s}$ and was reproduced in $600 \mathrm{~Hz}$ frequency. This light passed through a filter $(\lambda<$ $600 \mathrm{~nm}$ ), where a photodetector is protected by another filter $(\lambda<700 \mathrm{~nm})$ to reflect heat. A selective system of pulse amplification ignores all signals except fluorescence emitted during the measurement time $(0.3 \mathrm{~s})$.

\section{RESULTS AND DISCUSSION}

Analysis showed an increase in $F_{\phi}$ with rising temperature in all cultivars, reaching a maximum value at $45{ }^{\circ} \mathrm{C}$ followed by a decrease at $48{ }^{\circ} \mathrm{C}$ (figure 1 ). This expected behaviour can be used as an estimator of the non-reversible state resulting from heat effect on photosynthesis (Downton and Berry, 1982). In fact, differences between bean varieties were demonstrated by $F_{\phi}$ increase, with temperatures ranging from 40 to $50{ }^{\circ} \mathrm{C}$ (Pastenes and Horton, 1999).

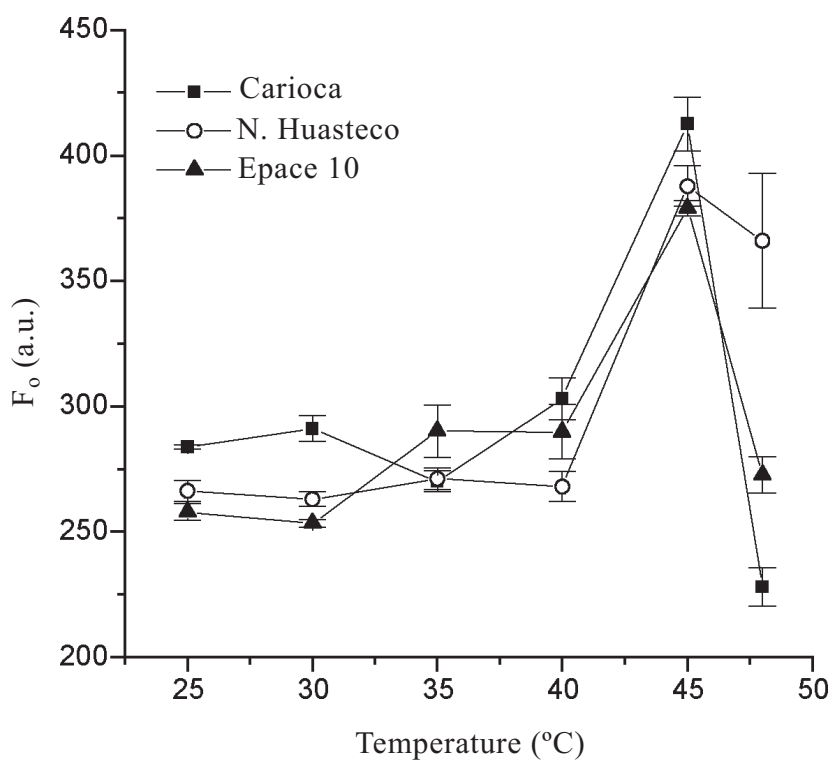

Figure 1. Initial fluorescence $F_{\phi}$ in Carioca and Negro Huasteco (P. vulgaris) and Epace 10 ( $\mathrm{V}$. unguiculata) submitted to different temperatures. The measurements were obtained $48 \mathrm{~h}$ after rising temperature treatment. Values are means $( \pm \mathrm{SD})$ of five replications.

According to Bolhàr-Noderkampf et al. (1989), the $F_{\phi}$ increase observed at $45{ }^{\circ} \mathrm{C}$ can indicate a reduction of energy transference to the PSII reaction centre or a partially-reversible inactivation (Yamane et al., 1997). The $F_{\phi}$ decrease at $48{ }^{\circ} \mathrm{C}$ could be explained by destruction of PSII reaction centre and formation of quenching species (Bolhàr-Noderkampf et al., 1989). This was particularly evident in Carioca and Epace 10, demonstrated by the death of the former. Surprisingly, 
Epace 10 showed a spectacular recovery of photochemical efficiency after $48 \mathrm{~h}$. Although $48{ }^{\circ} \mathrm{C}$ was lethal for Carioca, Negro Huasteco presented a minor decrease in $\mathrm{F}_{\phi}$. However, this cultivar did not survive at high temperature treatment. These results show that this parameter cannot be considered a good indicator for heat tolerance in bean species.

Even though the results shown in figure 1 are inconclusive about heat tolerance, table 1 shows a strong decrease in $F_{\max }$ in Carioca and Negro Huasteco with temperature increase, but not in Epace 10. The decreases in these cultivars may be associated with loss of PSII activity due to conformational changes in $\mathrm{D} 1$ protein (De las Rivas and Barber, 1997; Bukhov et al., 1999), causing alterations in PSII electron acceptor properties (Andréasson et al., 1995; Rova et al., 1998).

Other factors may be associated to $F_{\max }$ decrease caused by heat, such as a migration of damaged PSII reaction centres to non-stacked thylacoid regions, and as an acceleration of energy transference to nonfluorescent PSI (Yamane et al., 1997). Even so the $F_{\max }$ decrease may be due to disruption of electron donation from water to PSII because of loss of the manganese atom and extrinsic proteins from the oxygen evolution complex (Nash et al., 1985; Enami et al., 1994). Such events may be associated to susceptibility of Carioca and Negro Huasteco to high temperature.

The $F_{v} / F_{\max }$ parameter was proportional to the quantum yield of PSII ranging from 0.75 to 0.85 in normal plants as pointed out by Butler and Kitajima (1975) and
Bolhàr-Noderkampf et al. (1993). In this work, Carioca and Negro Huasteco showed a marked decrease in the $F_{v} / F_{\max }$ ratio at $48{ }^{\circ} \mathrm{C}$ indicating severe damage in the photochemical efficiency of PSII and susceptibility of these cultivars (figure 2). However, the $F_{v} / F_{\max }$ ratio in Epace 10 persisted in a range that does not characterise damage to PSII. In fact, when the $F_{v} / F_{\max }$ ratio values are compared among the cultivars, a decrease of 98.55 $\%, 100 \%$ and $5.05 \%$ is observed for Carioca, Negro Huasteco and Epace 10, respectively. Table 2 shows the dimension of damage promoted by heat stress in all cultivars.

The $F_{\phi}$ increase observed at $45^{\circ} \mathrm{C}$ can be explained by the initial damage occurring at PSII (figure 1) in all cultivars. Nevertheless, Epace 10 resisted the heating treatment, especially at $48{ }^{\circ} \mathrm{C}$, showing a small decrease in photochemical efficiency $(5.05 \%)$ in spite of the elevated $F_{\phi}$ values at this temperature. This increase in $F_{\phi}$ is dependent on structural conditions affecting the probability of the energy transference within the pigments of the light harvesting complex to the PSII reaction centre (Krause and Weis, 1984). As the $F_{\phi}$ increase occurred at $45^{\circ} \mathrm{C}$ and $F_{\max }$ was almost constant for Epace 10, the $F_{v} /$ $F_{\max }$ ratio showed little variation for this cultivar during recovery after $48 \mathrm{~h}$. In this investigation, response analysis of $F_{\phi}$ for all cultivars did not enable the discrimination of heat tolerance among them. Within the fluorescence parameters investigated, the $F_{v} / F_{\max }$ ratio and $F_{\max }$ showed the best suitability for heat tolerance discrimination, as proposed by Maxwell and Johnson (2000).

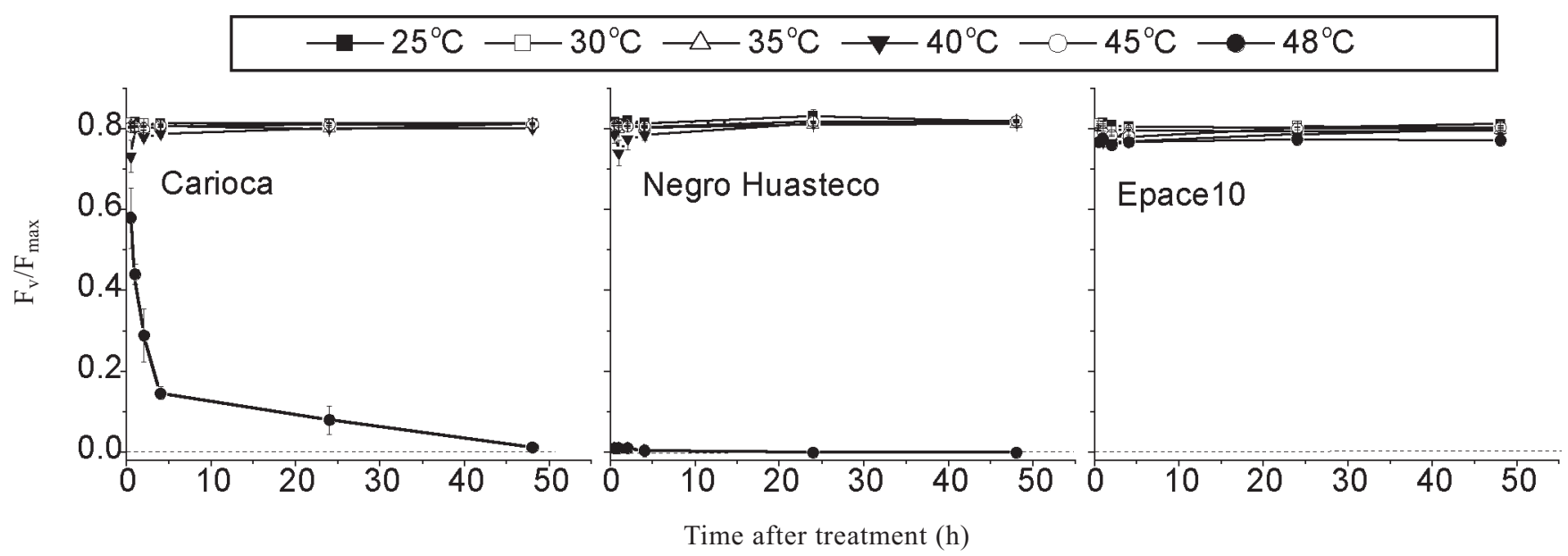

Figure 2. Photochemical efficiency of PSII $\left(\mathrm{F}_{\mathrm{v}} / \mathrm{F}_{\max }\right)$ in Carioca and Negro Huasteco (P. vulgaris) and Epace 10 (V. unguiculata) submitted to different temperatures. The measurements were obtained during $48 \mathrm{~h}$ after temperature treatment. Values are means $( \pm \mathrm{SD})$ of five replications. 
Table 1. Values of maximum fluorescence $\left(F_{\text {max }}\right)$ for the cultivars Carioca, Negro Huasteco (P. vulgaris) and Epace 10 (V. unguiculata), at $25{ }^{\circ} \mathrm{C}$ and $48{ }^{\circ} \mathrm{C}$, during recovery period after stress treatment $(48 \mathrm{~h})$.

\begin{tabular}{lcc}
\hline \multirow{2}{*}{ Cultivars } & \multicolumn{2}{c}{$F_{\max }$ Values } \\
\cline { 2 - 3 } & $25^{\circ} \mathrm{C}$ & $48{ }^{\circ} \mathrm{C}$ \\
\hline Carioca & $1491 \pm 38^{\mathrm{a}}$ & $225 \pm 15$ \\
Negro Huasteco & $1473 \pm 67$ & $377 \pm 80$ \\
Epace 10 & $1332 \pm 73$ & $1202 \pm 43$ \\
\hline
\end{tabular}

${ }^{a}$ Values are means $( \pm S D)$ of five replications.

Table 2. Photochemical efficiency $\left(F_{v} / F_{\max }\right)$ for the cultivars Carioca, Negro Huasteco (P. vulgaris) and Epace 10 (V. unguiculata), at 25,45 and $48^{\circ} \mathrm{C}$ at different temperatures, $48 \mathrm{~h}$ after the treatment. The temperature of $25^{\circ} \mathrm{C}$ was considered as the control.

\begin{tabular}{lccc}
\hline Cultivars & $25^{\circ} \mathrm{C}$ & $45^{\circ} \mathrm{C}$ & $48^{\circ} \mathrm{C}$ \\
& $F_{v} / F_{\max }$ & $F_{v} / F_{\max }(\%$ control $)$ & $F_{v} / F_{\max }(\%$ control $)$ \\
\hline Carioca & $0.813^{\mathrm{a}}$ & $0.812(99.87)$ & $0.012(1.45)$ \\
Negro Huasteco & 0.812 & $0.820(100.24)$ & $0.000(0.00)$ \\
Epace10 & 0.813 & $0.804(98.89)$ & $0.772(94.95)$ \\
\hline
\end{tabular}

${ }^{\text {a }}$ Values are means $( \pm S D)$ of five replications.

According to the results obtained, the photosynthetic apparatus of Epace 10 presented differential tolerance to heat stress while that of Carioca and Negro Huasteco did not. The cultivars investigated are known to differ in their capacity to resist detrimental effects of high temperature. Carioca is not recommended for cultivation in warm regions with persistently high temperature periods, unlike Negro Huasteco, a cultivar considered tolerant to supraoptimum temperature (Masaya and White, 1991) and Epace 10, widely distributed in warm and dry regions in Brazil. An important feature of these results is that, although the photosynthetic apparatus of Negro Huasteco was less tolerant than other cultivars investigated in this work, this cultivar is recommended for warm regions. Consequently, other morphophysiological characteristics must probably be involved in tolerance capacity. According to McDonald and Paulsen, (1997), the photosynthetic apparatus of Epace 10 makes use of mechanisms of tolerance to heat stress. Some speculations can be made such as: (a) major capacity of D1 protein regeneration; (b) high activity of the xanthophyll cycle and (c) high capacity for energy dissipation via the proton gradient in thylacoids. Nevertheless, these considerations are to be investigated.

\section{REFERENCES}

Andréasson L-E, Vass I, Styring S (1995) $\mathrm{Ca}^{2+}$ depletion modifies the electron transfer on the both donor and acceptor sides in photosystem II from spinach. Biochim. Biophys. Acta 1230:155-164.

Berry J, Björkman O (1980) Photosynthetic response and adaptation to temperature in higher plants. Annu. Rev. Plant Physiol. 31:491-543.

Bolhàr-Nordenkampf HR, Long SP, Baker NR, Öquist G, Shureiber UE, Lechner EG (1989) Chlorophyll fluorescence as probe of the photosyntetic competence of leaves in the field: a review of current instrumentation. Func. Ecol. 3:497-514.

Bolhàr-Nordenkampf HR, Öquist G (1993) Chlorophyll fluorescence as a tool in photosynthesis research. In: Hall DO, Scurlock JMO, Bolhàr-Nordenkamppf HR, Legood RC, Long SP (eds), Photosynthesis and production in a changing environment: a field and laboratory manual. Chapman and Hall, London.

Briantais J-M, Dacosta J, Goulas Y, Ducruet J-M, Moya I (1996) Heat stress induces in leaves an increase of the minimum level of chlorophyll fluorescence, $\mathrm{F}_{0}$ : a timeresolved analysis. Photosynth. Res. 48:189-196.

Bulkhov N, Wiese C, Neimanis S, Heber U (1999) Heat sensitivity of chloroplasts and leaves: Leakage of protons from thylakoids and reversible activation of cyclic eletron transport. Photosynth. Res. 59:81-93.

Butler WL, Kitajima M (1975) A tripartite model for chloroplast fluorescence. In: Avron M (ed), Proceedings of the 3 rd International Congress on Photosynthesis. pp. 13-24.

Downton WJ, Berry J (1982) Chlorophyll fluorescence at high temperature. Biochim. Biophys. Acta 679:474-478.

De Las Rivas J, Barber J (1997) Structure and thermal stability of photosystem II reaction centers studied by infrared spectroscopy. Biochemistry 36:88978903.

Enami I, Kitamura M, Tomo T, Isokawa Y, Ohta H, Katch S (1994) Is the primary cause of thermal inactivation of oxygen evolution in spinach PS II membranes release of the extrinsic $33 \mathrm{kDa}$ protein or of $\mathrm{Mn}$ ? Biochim. Biophys. Acta 1186:52-58.

Gilmore AM, Govindjee (1999) How higher plants respond to excess light: energy dissipation in photosystem II. In: Singhal, Gs, Renger, G, Sopory, Sk, Irrgang, K-D, Govindjee (eds), Concepts in photobiology: photosynthesis and photomorphogenesis, pp. 513-548. Narosa Publ. House, New Delhi, India. 
Gounaris K, Brain APR, Quinn PJ, Williams WP (1983) Structural and functional changes associated with heated-induced phase separations of no-bilayer lipids in chloroplast thylakoid membranes. FEBS Lett. 153:47-52.

Havaux M, Ernez M, Lannoye R (1988) Correlation between heat tolerance and drought tolerance in cerals demonstrated by rapid chlorophyll fluorescence. J. Plant Physiol. 133: 555-560.

Jones LH (1971) Adaptative responses to temperature in dwarf french beans, Phaseolus vulgaris L. Ann. Bot., 35: 581-596.

Krause GH, Weis E (1984) Chlorophyll fluorescence as a tool in plant physiology. II. Interpretation of fluorescence signals. Photosynth. Res. 5:139-157.

Mcdonald GK, Paulsen GM (1997) High temperature effects on photosynthesis and water relations of grain legumes. Plant Soil 196:47-58.

Masaya P, White JW (1991) Adaptation to photoperiod and temperature. In: Van Schoonhoven A, Voysest O (eds), Common beans- Research for crop improvement, pp. 445-500. CIAT, Cali, Colômbia.

Maxwell K, Johnson GN (2000) Chlorophyll fluorescence - A pratical guide. J. Exp. Bot. 51: 659-668.

Nash D, Miyao M, Murata N (1985) Heat inactivation of oxygen evolution in Photosystem II particles and its acceleration by chloride depletion and exogenous manganese. Biochim. Biophys. Acta 807:127-133.

Pastenes C, Horton P (1996a) Effect of high temperature on photosynthesis in beans. I. Oxygen evolution and chlorophyll fluorescence. Plant Physiol. 112:1245-1251.
Pastenes C, Horton P (1996b) Effect of high temperature on photosynthesis in beans. II. $\mathrm{CO}_{2}$ assimilation and metabolite contents. Plant Physiol. 112:1253-1260.

Pastenes C, Horton P (1999) Resistance of photosynthesis to high temperature in two bean varieties (Phaseolus vulgaris L.) Photosynth. Res. 62: 197-203.

Pimentel C (1998) Metabolismo de carbono na agricultura tropical. EDUR, Seropédica, RJ, Brazil.

Raison JK, Roberts JKM, Berry JA (1982) Correlations between thermal stability of chloroplast (thylakoid) membranes and the composition and fluidity of their polar lipids upon acclimation of the higher plant Nerium oleander, to growth temperature. Biochim. Biophys. Acta 688:218-228.

Rova M, Mamedov F, Magnuson A, Freriksson P-O, Styring S (1998) Coupled activation of the donor and acceptor side of photosystem II during photoactivation of the oxygen evolving cluster. Biochemistry 37:11039-11045.

Regras para análise de sementes (1992) SNDA - Serviço Nacional de Desenvolvimento Agrário/Ministério da Agricultura e Reforma Agrária: SNDA/DNDV/ CLAV.

Yamane Y, Kashino Y, Koile H, Satoh K (1997) Increase in the fluorescence $F_{0}$ level reversible inhibition of Photosystem II reaction center by high-temperature treatments in higher plants. Photosynth. Res. 52:57-64.

Yamane Y, Kashino Y, Koike H, Satoh K (1998) Effects of high temperatures on the photosynthetic systems in spinach: oxygen-evolving activities, fluorescence characteristics and the denaturation process. Photosynth. Res. 57:51-59. 